BNWL-153

$50-$
RESEARCH

and

\section{DEVELOPMENT}

REPORT

\title{
EFFECTS OF NEUTRON IRRADIATION UPON THE MECHANICAL PROPERTIES OF INCONEL 625
}

\author{
T. T. CLAUDSON
}

OCTOBER, 1965

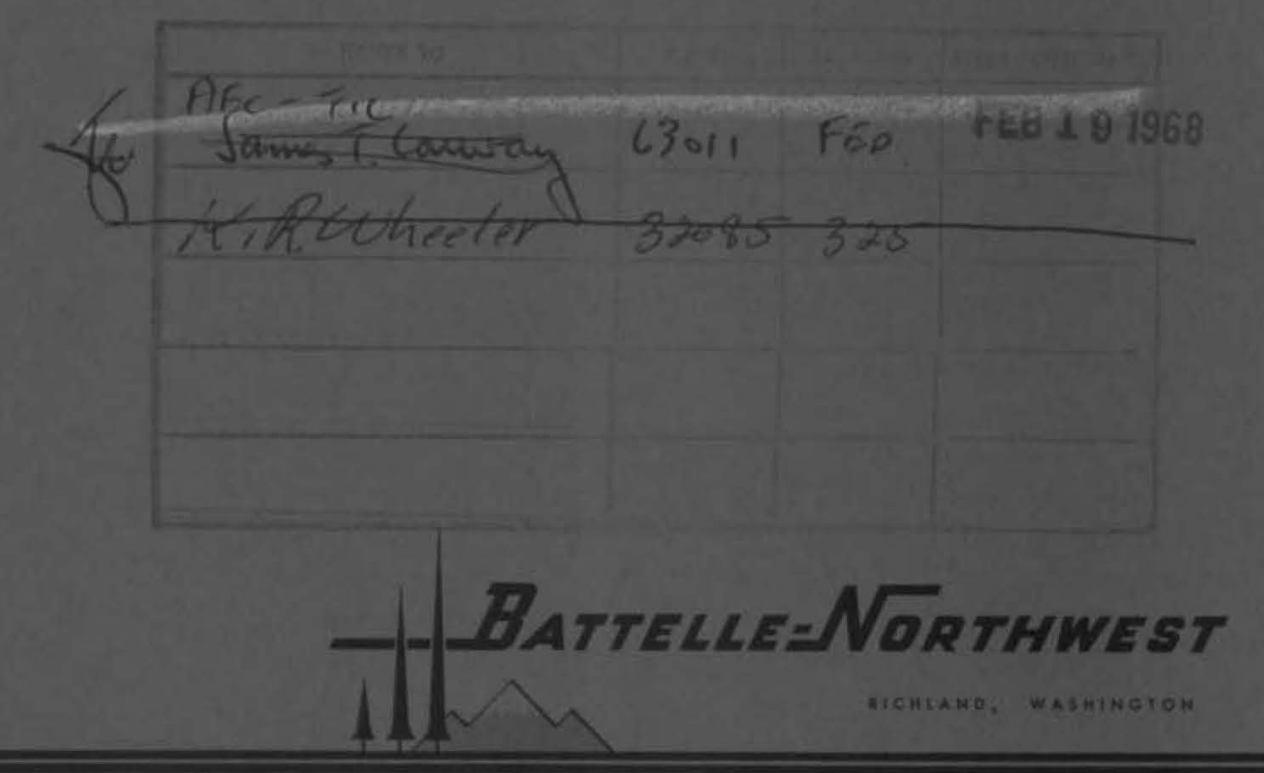

PACIFIC NORTHWEST LABORATORY operated bY BATTELLE MEMORIAL INSTITUTE 


\section{LEGAL NOTICE}

This report was prepared as an account of Government sponsored work. Neither the United States, nor the Commission, nor any person acting on behalf of the Commission:

A. Makes any warranty or representotion, expressed or implied, with respect to the accuracy, completeness, or usefulness of the information contained in this report, or that the use of any information, apparatus, method, or process disclosed in this report may not infringe privately owned rights; or

B. Assumes any liabilities with respect to the use of, or for damages resulting from the use of ony information, apparatus, method, or process disclosed in this report.

As used in the above, "person acting on behalf of the Commission" includes any employee or contractor of the Commission, or employee of such contractor, to the extent that such employee or contractor of the Commission, or employee of such contractor prepares, disseminates, or provides access to, any information pursuant to his employment or contract with the Commission, or his employment with such contractor.

\section{PACIFIC NORTHWEST LABORATORY \\ RICHLAND, WASHINGTON \\ operated by \\ BATTELLE MEMORIAL INSTITUTE}

for the

UNITED STATES ATOMIC ENERGY COMMISSION UNDER CONTRACT AT(45-1)-1830 


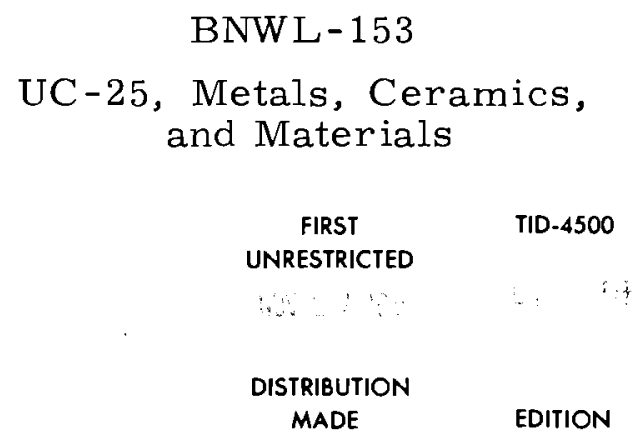

EFFECTS OF NEUTRON IRRADIATION

UPON THE MECHANICAL PROPERTES OF INCONEL 625

\author{
By \\ T. T. Claudson \\ Metallurgy Research Section \\ Reactor and Materials Technology Department
}

October, 1965

PACIFIC NORTHWEST LABORATORY

RICHLAND, WAS HINGTON 


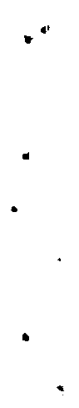




\title{
TABLE OF CONTENTS
}

\begin{abstract}
Page
INTRODUCTION •

SUMMARY AND CONCLUSIONS $\quad$ •

IRRADIATION ENVIRONMENTS AND TEST CONDITIONS . . . 5

TEST RESULTS • • • . . . . . . . . . . . . . 11

A. Effects of Irradiation Upon the Room Temperature

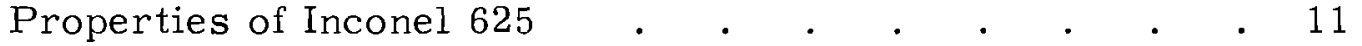

B. Effects of Irradiation Upon the Elevated Temperature Mechanical Properties of Inconel 625 • • • . • . . 15
\end{abstract}




\section{EFFECTS OF NEUTRON IRRADIATION}

UPON THE MECHANICAL PROPERTIES OF INCONEL 625

\section{INTRODUCTION}

The orderly development of new reactor concepts and technology depends upon the availability of new alloys that are capable of operating in more stringent environments and at higher temperatures than now exist in operating reactors. To provide higher thermal efficiencies, the nuclear superheat reactor concept has been employed, whereby higher operating temperatures are achieved. Operating conditions of the superheat regions of these reactors preclude the use of the common austenitic stainless steels and zirconium alloys. Alloys that have better high temperature strength and oxidation resistance must be used.

As a part of a USAEC-sponsored program to determine the effects of irradiation and environment upon the properties of reactor structural metals, several nickel base precipitation and solution hardenable alloys are being evaluated under various reactor conditions. A survey of the preirradiation mechanical properties and oxidation resistance of these nickel base alloys indicated that Inconel $625 \mathrm{might}$ be suitable for many reactor structural components, including fuel cladding.

Inconel 625 is a relatively new alloy developed by International Nickel Company, Inc. It is a nickel-chromium-iron alloy whose high strength results from adding molybdenum and columbium to the nickel-chromium matrix. Therefore, the material is not a precipitation-hardenable alloy and, in the hot-rolled and annealed condition, does not show the typical ductility decrease in the nickel base alloy range of 760 to $870{ }^{\circ} \mathrm{C}$.

The oxidation resistance of Inconel 625 has been found to be comparable to other nickel base alloys. ${ }^{1}$ A tight, adherent, protective, oxide film forms on the metal surface and forms with a minimum amount of intergranular

\footnotetext{
${ }^{1}$ T. T. Claudson and H. J.. Pessl. Irradiation Effects on High Temperature Reactor Structural Metals, BNWL-23. February 25, 1965.
} 
attack. Because of its relatively high strength and oxidation resistance, Inconel 625 has been considered as a candidate material for fuel cladding for nuclear superheat reactors. Therefore, it is necessary to determine the effects of irradiation upon its mechanical properties.

SUMMARY AND CONCLUSIONS

The studies within this report have shown the effects of neutron irradiation, test temperature, irradiation temperature, and material condition upon the mechanical properties of the solution hardenable alloy, Inconel 625 .

The room temperature tensile properties are characterized by increases in yield strength with some loss in ductility at low $\left(50{ }^{\circ} \mathrm{C}, 280{ }^{\circ} \mathrm{C}\right)$ irradiation temperatures. Essentially, there was no change within the limits of experimental error in ultimate strength. Material irradiated at these lower temperatures and tested at room temperature maintained good ductility as shown by high uniform and total elongations and large reductions in area. Necking occurred because of plastic instability in a localized region of all specimens irradiated and tested under these conditions.

The major effect found in the room temperature properties of Inconel 625 was caused by irradiation temperature. These data, however, when compared to control specimens, indicate that the effect is primarily because of the thermal environment and not the irradiation since the control specimens also showed a decrease in ductility. This is especially true for the $740^{\circ} \mathrm{C}$ irradiation temperature. At the $580^{\circ} \mathrm{C}$ irradiation temperature, a further decrease in ductility was observed in the irradiated specimen as compared to the control specimen. This decrease indicated some effect of irradiation. Essentially, no effect was noticed for specimens irradiated at $740{ }^{\circ} \mathrm{C}$. At $740{ }^{\circ} \mathrm{C}$, the only effects were increases in yield and ultimate strength. Although structural components of Inconel 625 will normally operate at elevated temperatures in reactor service, they will also operate satisfactorily under applied stress at lower temperatures during reactor shut down.if adequate design condiserations are applied. 
Unirradiated specimens of Inconel 625 exposed to superheated steam at $1150^{\circ} \mathrm{F}$ over long periods of time, increased in yield strength and decreased in room temperature elongations. ${ }^{1}$ These effects stabilized after about $4000 \mathrm{hr}$. The elongation values of over $20 \%{ }^{1}$ after exposure agree with the values from $580^{\circ} \mathrm{C}$ control exposures in this study. Comprelli and Wolff $^{1}$ also showed that long term exposure of Inconel 625 to high temperature environments caused precipitation. The precipitates were primarily the $\mathrm{AB}$ type, $\mathrm{T}$ iN and $\mathrm{NbC}$.

Since the precipitation of inherently brittle second phases occur at elevated temperature (where the alloy is expected to operate) the elevated temperature mechanical properties are of great interest.

The elevated temperature tests on specimens irradiated at $280^{\circ} \mathrm{C}$ show a marked decrease in ductility as compared to similar specimens tested at room temperature. It is important to note that this reduction does not seem as dependent upon the irradiation dosage as it is upon the testing temperature. At both test temperatures, only small changes in the percent uniform elongation occurred, compared to a factor of 3 to 4 decrease associated with the difference in test temperature alone.

It appears from the elevated temperature test data that the reduction in strength properties of the material are caused primarily by the effects of the neutron irradiation since significant changes in the yield strengths were found as compared to the control specimens. The reduction in strength may be due to defects in the material relaxing the matrix strain hardening imposed by the solution hardening elements of the alloy, columbium and molybdenum. In comparing the percent uniform elongation data for both the control and irradiated specimens with the as heat treated value, a marked decrease is observed. This decrease indicates that exposure of the material to its test environment is the primary cause of the reduced ductility because

${ }^{1}$ F. A. Comprelli and U. E. Wolff. Stability of High-Nickel Alloys in Superheated Steam, GEAP-4745. General Electric Company, San Jose, California. November, 1964. 
of thermal aging. Thus, it appears that two mechanisms may be operating to cause the observed changes in the mechanical properties of the alloy. One mechanism is associated with the neutron exposure controlling the strength properties, the other is associated with the thermal exposure controlling the ductility of the material.

This apparent small effect of irradiation upon the high temperature ductility of Inconel 625 was not discovered in specimens irradiated at $740{ }^{\circ} \mathrm{C}$. Specimens irradiated to an exposure of $9.2 \times 10^{20} \mathrm{nvt}(\mathrm{E}>1 \mathrm{MeV})$ showed a factor of 2 decrease in uniform elongation. This decrease indicates irradiation-induced damage in the material. This observation was also made for the solution hardenable nickel base alloy Hastelloy $\mathrm{N}$ at Oak Ridge National Laboratory. ${ }^{1}$

Examination of the data for specimens irradiated at $740{ }^{\circ} \mathrm{C}$ in the millannealed and in the solution-treated and aged conditions and tested both at room temperature and at $650^{\circ} \mathrm{C}$, reveals that the ductility of the material at both test temperatures is lower after $740{ }^{\circ} \mathrm{C}$ irradiation than after $280^{\circ} \mathrm{C}$ irradiation. For the room temperature tests, the material increased in yield and ultimate strength because of the $740{ }^{\circ} \mathrm{C}$ irradiation. The converse was true in material tested at $650^{\circ} \mathrm{C}$ where a decrease in the strength properties was observed. In addition, a greater change in strength and ductility due to irradiation was seen at the $650{ }^{\circ} \mathrm{C}$ test temperature. It also appears that material in the solution treated condition prior to the irradiation retains more ductility during elevated temperature neutron exposure.

It is concluded from these investigations that thermal exposure plays an important role upon the mechanical properties of Inconel 625 after irradiation. Thermal stability of this alloy at elevated temperatures in absence

${ }^{1}$ W. R. Martin and J. R. Weir. Effect of Elevated Temperature Irradiation on the Strength and Ductility of the Nickel-Base Alloy, Hastelloy N,

ORNL-TM-1005, Oak Ridge, Tennessee. February, 1965. 
of neutrons is good with most precipitation reactions occurring slowly at temperature of $620^{\circ} \mathrm{C}$. At temperature of $740^{\circ} \mathrm{C}$, these reactions must surely increase in rate; and in the presence of high energy neutrons, may occur even faster. The extent and distribution of the precipitation and their effects upon the mechanical properties of the material should be the subject of further research.

IRRADIATION ENVIRONMENTS AND TEST CONDITIONS

Material used in these studies was obtained from the vendor as $0.250 \mathrm{in.} \mathrm{plate} \mathrm{stock} \mathrm{in} \mathrm{annealed} \mathrm{and} \mathrm{pickled} \mathrm{condition.} \mathrm{The} \mathrm{certified} \mathrm{chem-}$ ical analysis of this material is given in Table I. After hot rolling, the material was annealed at $1150^{\circ} \mathrm{C}$ for $1 \mathrm{hr}$ and air cooled. Further plate reduction was necessary to fabricate tensile specimens of the geometry shown in Figure 1. Prior to fabrication of the tensile specimens, the 0.250 in. plate was hot rolled (according to the rolling schedule shown in Table II) to a nominal thickness of $0.110 \mathrm{in.} \mathrm{No} \mathrm{reheating} \mathrm{was} \mathrm{required}$ during the rolling. After rolling, the material was sand blasted, washed, roller leveled, and annealed. The material was annealed at $1040{ }^{\circ} \mathrm{C}$ for $1 \mathrm{hr}$ and air cooled. Because of slight warpage from the annealing operation, the material was again roller leveled and flattened.

TABLE I

CHEMICAL ANALYSIS OF INCONEL 625

Heat Number NX 8137A

Chemical, wt\%

$\frac{\mathrm{C}}{0.033} \frac{\mathrm{Ni}}{62.62} \frac{\mathrm{Cr}}{21.81} \quad \frac{\mathrm{Fe}}{1.46} \quad \frac{\mathrm{Cb}}{3.97} \quad \frac{\mathrm{Mo}}{8.99} \quad \frac{\mathrm{S}}{0.006} \frac{\mathrm{P}}{0.005} \quad \frac{\mathrm{Si}}{0.22} \frac{\mathrm{B}}{<0.001}$

$\frac{\mathrm{Ta}}{<0.01} \frac{\mathrm{N}}{0.047} \frac{\mathrm{H}}{0.0006} \frac{\mathrm{O}}{0.011} \frac{\text { Total rare earths }}{20 \mathrm{ppm}}$

${ }^{I}$ F. A. Comprelli and U. E. Wolff. Stability of High-Nickel Alloys in Superheated Steam, GEAP-4745. General Electric Company, San Jose, California, November, 1964. 


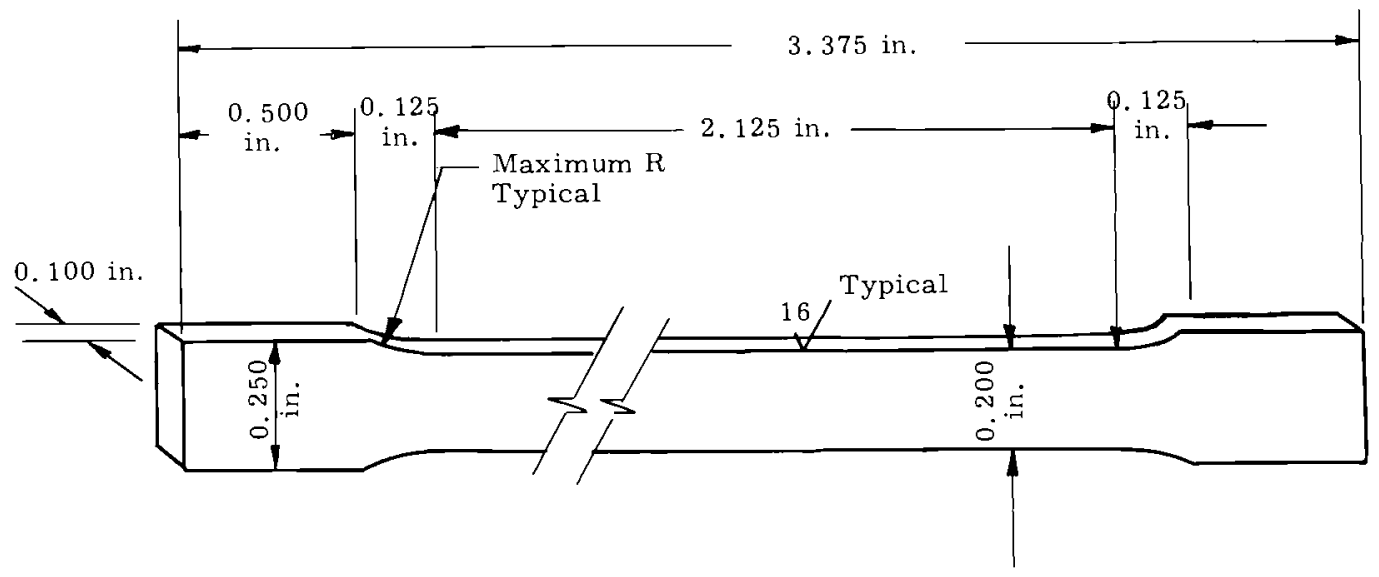

FIGURE 1

Specimen Geometry Used to Determine the Effects of Irradiation Upon the Mechanical Properties of Inconel 625

TABLE II

ROLLING SCHEDULE FOR INCONEL 625

Heat Number NX 8137A

$\begin{array}{ccc}\text { Pass No. } & \text { Gage Width, in. } & \text { Temperature } \\ & 0.250 & \\ 2 & 0.210 & \\ 3 & 0.176{ }^{\circ} \mathrm{C} * \\ 4 & 0.155 & \\ 5 & 0.135 & \\ 6 & 0.120-0.127 & \\ 7 & 0.113-0.116 & \end{array}$

The resulting $0.110 \mathrm{in}$. sheets were given a solution and aging treatment. The material was heated to a temperature of $1040^{\circ} \mathrm{C}$ for $1 \mathrm{hr}$, water quenched, reheated to $705{ }^{\circ} \mathrm{C}$ for $24 \mathrm{hr}$, and water quenched. The properties of the material from this heat treatment were quite similar to the vendor's properties for this specific heat treatment. Additional material was set aside in the as-worked and annealed condition for comparison to the heat treated material. 
Flat tensile specimens were then fabricated by surface grinding, to the dimensions shown in Figure 1. To insure the fabrication of reproducible specimens, jigs were used, whereby 30 specimens could be produced at one time. Identical grinding procedures were followed for each set of specimens that were subsequently accurately measured and weighed prior to the irradiation.

Since a reactor material may be used in a variety of temperature ranges, specimens of Inconel 625 were irradiated at 50 and $280^{\circ} \mathrm{C}$ in water, and at average temperatures of 580 and $740^{\circ} \mathrm{C}$ in a predominately helium environment. Neutron exposure levels in the water environments were between $4 \times 10^{19}$ and 1.46 and $10^{21}$ nvt $(\mathrm{E}>1 \mathrm{MeV})$. The exposure levels for the higher temperature irradiations were $9.2 \times 10^{19} \mathrm{nvt}$ and $1.92 \times 10^{20} \mathrm{nvt}(\mathrm{E}>1 \mathrm{MeV})$.

Tensile specimens of the identical material were given similar thermal and environmental treatments out-of-reactor and tested as control specimens. However, specimens in the preirradiation condition were tested as control specimens for the $50{ }^{\circ} \mathrm{C}$ irradiations and no additional thermal conditioning was given. Control specimens for material that was irradiated in the Engineering Test Reactor (ETR) G-7 hot water loop facility at $280{ }^{\circ} \mathrm{C}$ were exposed to an out-of-reactor loop facility which duplicated temperature conditions and water chemistry found in the in-reactor facility. Thermal and environmental conditions for the 580 and $740^{\circ} \mathrm{C}$ irradiations were simulated by encapsulating specimens in helium and placing them in a laboratory furnace at the appropriate temperatures for an equivalent number of reactor operating hours. After exposure, the control specimens were tested identically to the irradiated specimens.

After irradiation, specimens were returned to the Radiometallurgy Laboratory for testing. Immediately after discharge from the cask, specimens were weighed, and dimensional and hardness measurements were made. The specimens were then tested under one of two procedures. The procedure depended upon which of three test temperatures was used. The test temperatures used in this investigation were room temperature, 300 , and $650{ }^{\circ} \mathrm{C}$. 
Specimens tested at room temperature were tested in an Instron tensile machine at a constant strain rate of $0.005 \mathrm{in}$. / in. $/ \mathrm{min}$. A standard Baldwin PM-3A extensometer was used to measure the specimen extension.

Those specimens tested at $300^{\circ} \mathrm{C}$ were placed into a furnace (Figure 2). After the specimen was inserted and the extensometer positioned, 20 min were required to bring the specimen to equilibrium temperature. At equilibrium temperature, the specimen was pulled at a constant strain rate of $0.05 \mathrm{in.} / \mathrm{in} . / \mathrm{min}$. The extension was measured by a modified PM-3A type extensometer calibrated at the test temperature.

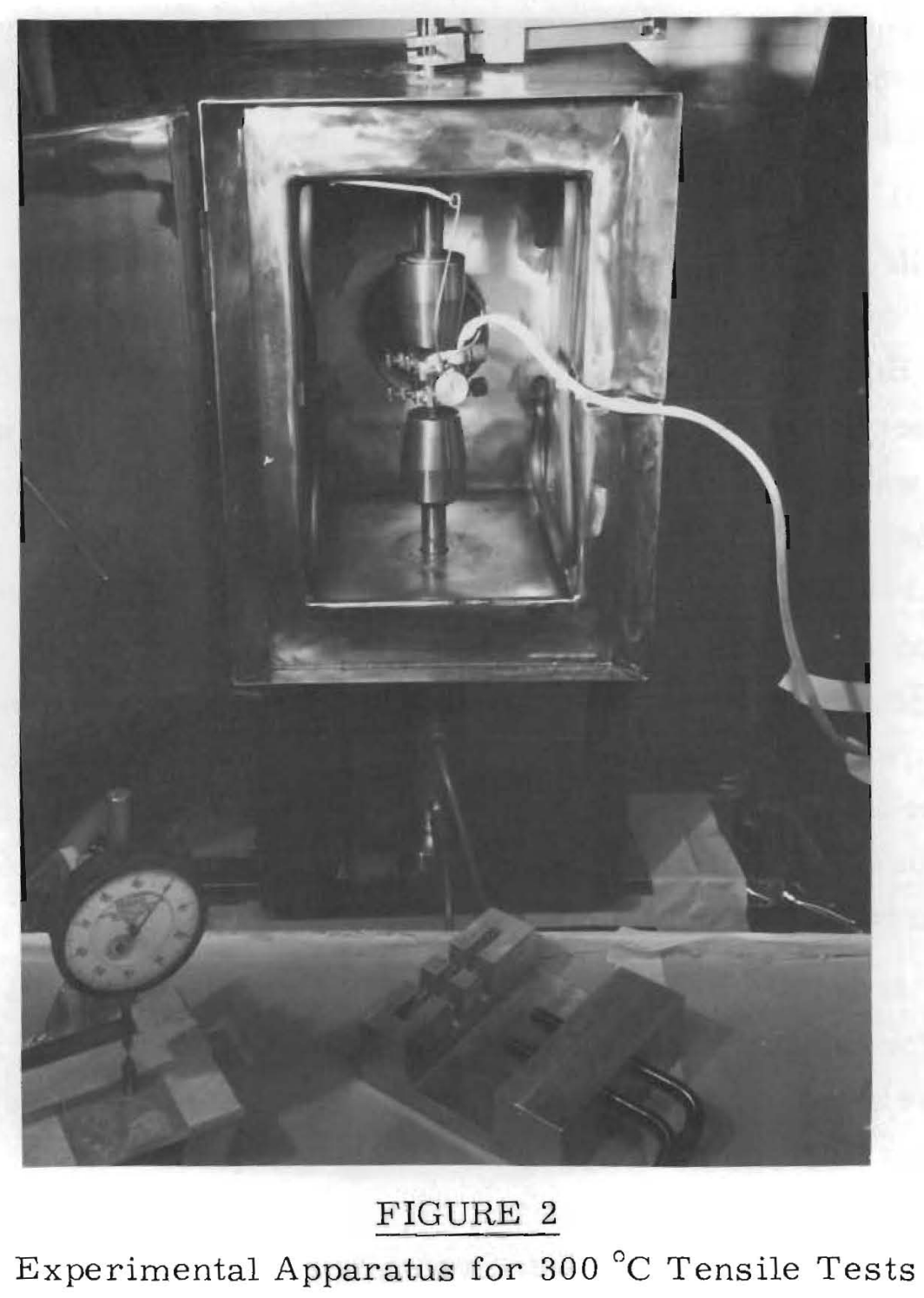

Neg. 0632847-2 
The control tests at $650{ }^{\circ} \mathrm{C}$ were performed in a 3-stage Marshall furnace (Figure 3) using an extended type extensometer (extensometer not attached). A strain rate of $0.05 \mathrm{in.} / \mathrm{in}$./min was used. Special grips were

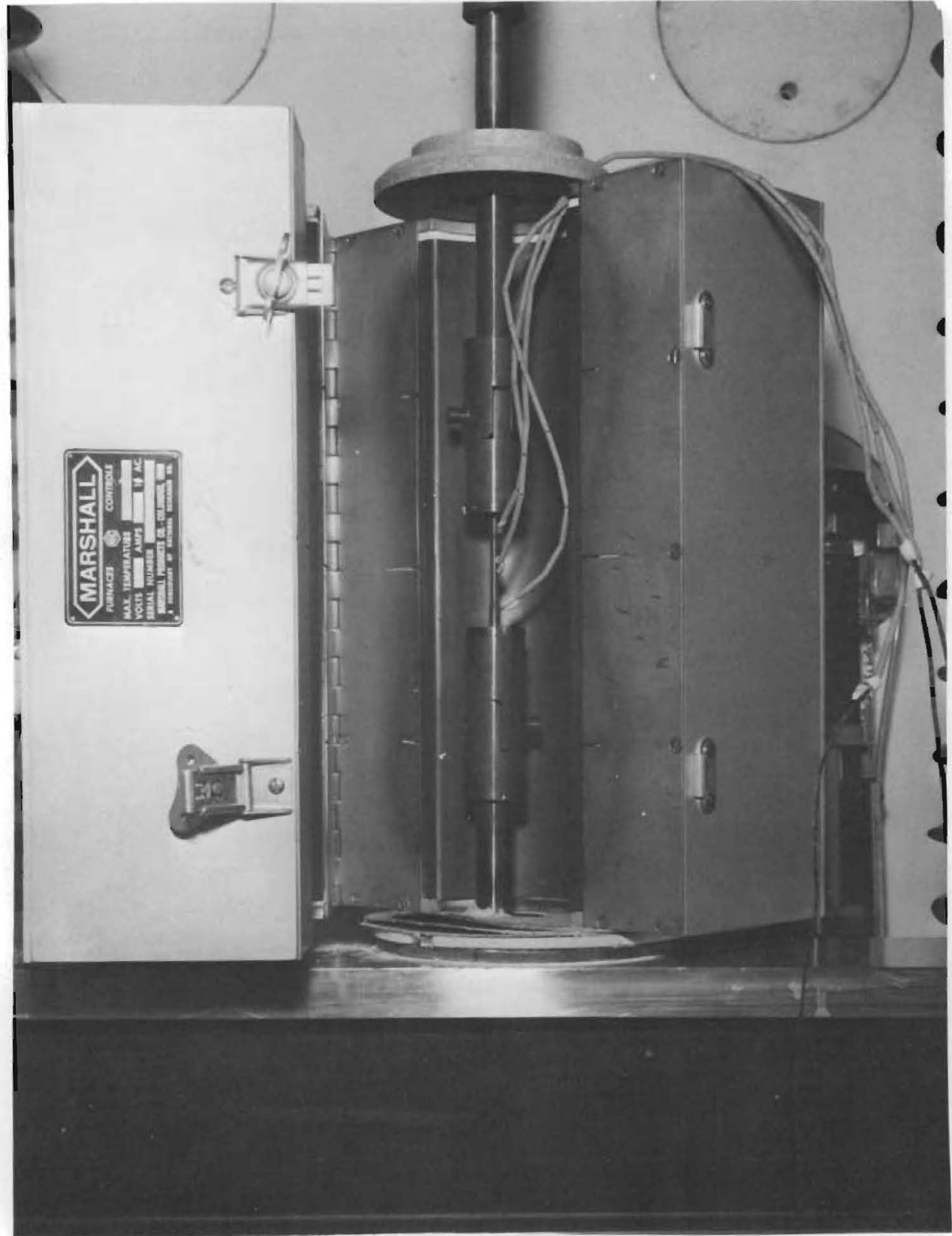

FIGURE 3

Experimental Apparatus for $650^{\circ} \mathrm{C}$ Control Tensile Tests

Neg. 0642150-2 
developed by using a titanium carbide insert for gripping the specimen. Radioactive specimens, tested at this temperature, were tested at the same strain rate using a similar extensometer in a hard beam Tinius Olson machine. A Marshall tantalum element, resistance furnace was used in these tests, and the tests were performed in vacuum. The test apparatus is shown in Figure 4.

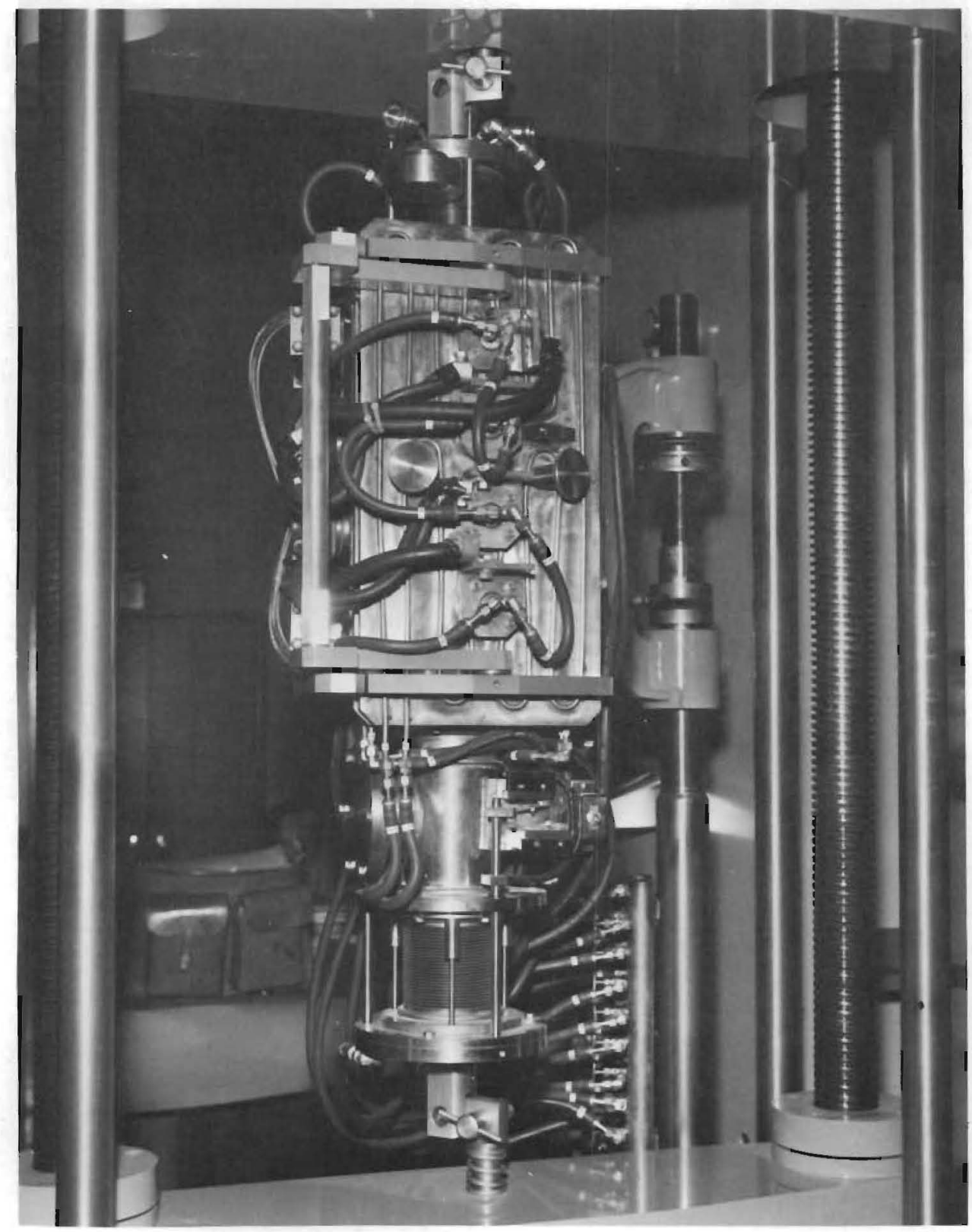

FIGURE 4

High Temperature Vacuum Furnace

Used for Elevated Temperature Tensile Tests

Neg. 0640968-3 


\section{TEST RESULTS}

\section{A. Effects of Irradiation Upon the Room Temperature Properties of Inconel 625}

The results of room temperature $\left(20^{\circ} \mathrm{C}\right)$ tests performed upon irradiated specimens are shown in Figures 5, 6, and 7 . Figure 5 shows the effects of neutron exposures of $7.64 \times 10^{20} \mathrm{nvt}(\mathrm{E}>1 \mathrm{MeV})$ upon the yield strength, ultimate tensile strength, percent uniform elongation, and percent reduction in area of Inconel 625 after irradiation at $50{ }^{\circ} \mathrm{C}$. As compared to the unirradiated control specimens, the irradiated specimens showed a large increase in strength with a corresponding decrease in uniform elongation. At an exposure of $7.64 \times 10^{20} \mathrm{nvt}$, the yield strength increased $72 \%$ to a value of 160,600 psi. Only a small increase in ultimate strength (7\%) was observed. The uniform elongation was only $8.4 \%$ at this exposure, but a large reduction in area was evident and indicated local plastic instability at the fracture section of the specimen.

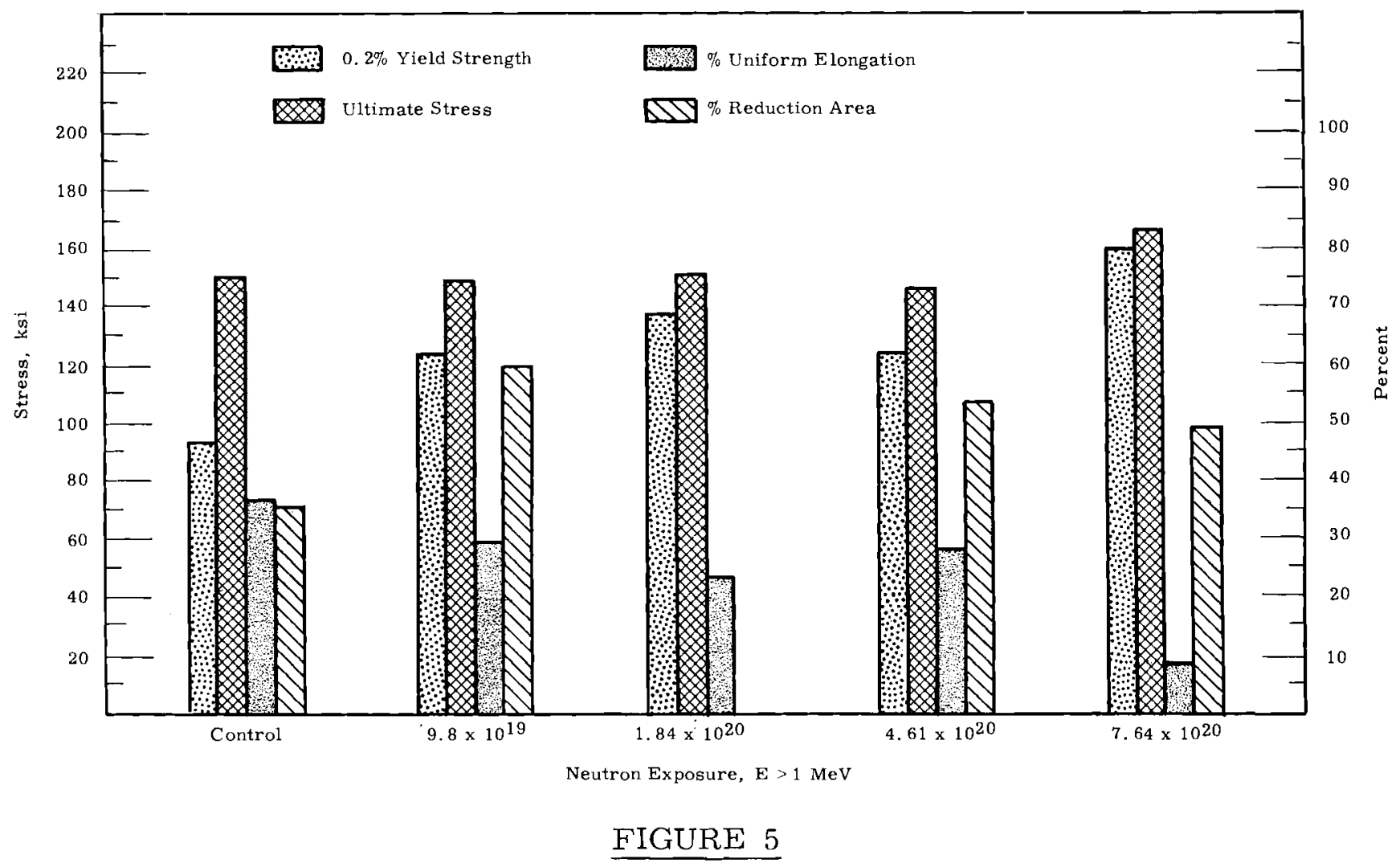

Effects of Neutron Irradiation Upon the Room Temperature Properties of Inconel 625 Irradiated at $50{ }^{\circ} \mathrm{C}$ in the Solution Treated Condition 
Figure 6 summarizes the results of tests performed on specimens irradiated at $280{ }^{\circ} \mathrm{C}$ and tested at room temperature. These specimens were irradiated to a maximum exposure of $8.27 \times 10^{20} \mathrm{nvt}(\mathrm{E}>1 \mathrm{MeV})$. Although the increases in strength are smaller than for specimens irradiated at $50{ }^{\circ} \mathrm{C}$, a substantially higher percent uniform elongation was found. This elongation exceeded $30 \%$ at the maximum exposure tested. There was found little or no effect of the irradiation upon the percent reduction in area or ultimate tensile strength of the material. Also, only small variations in ductility were found throughout the exposure range.

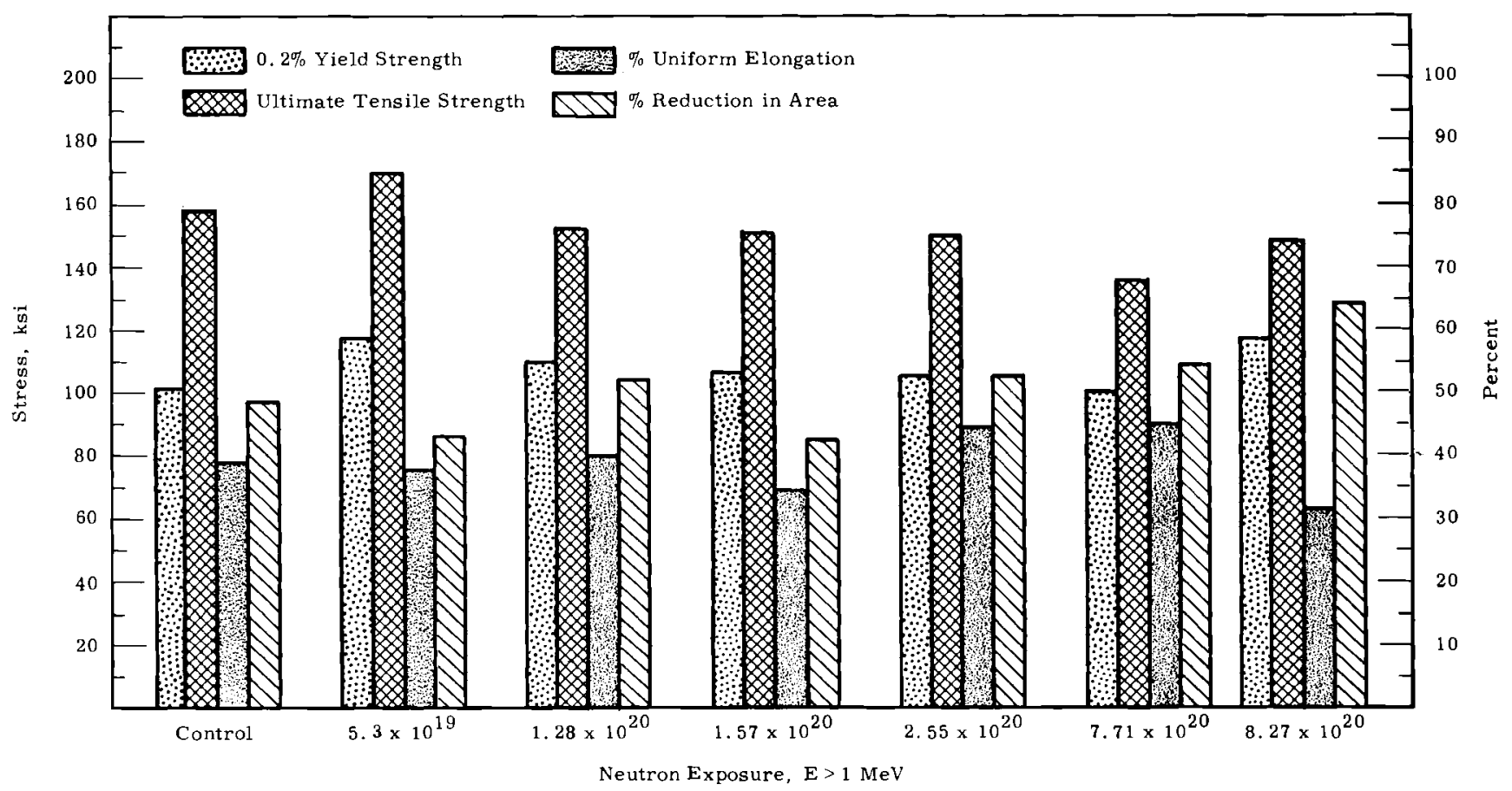

FIGURE 6

Effects of Neutron Irradiation Upon the Room Temperature Properties of Inconel 625 Irradiated at $280^{\circ} \mathrm{C}$ in the Solution Treated Condition

Additional specimens were tested at room temperature after irradiation at 580 and $740^{\circ} \mathrm{C}$ to an exposure of about $9 \times 10^{19} \mathrm{nvt}(\mathrm{E}>1 \mathrm{MeV})$. The results of these tests are shown in Figure 7 . For convenience, all the room temperature data for specimens irradiated at about $1 \times 10^{20}$ nvt have also been plotted for comparison and show the effect of the irradiation temperature upon the room temperature properties of Inconel 625. 


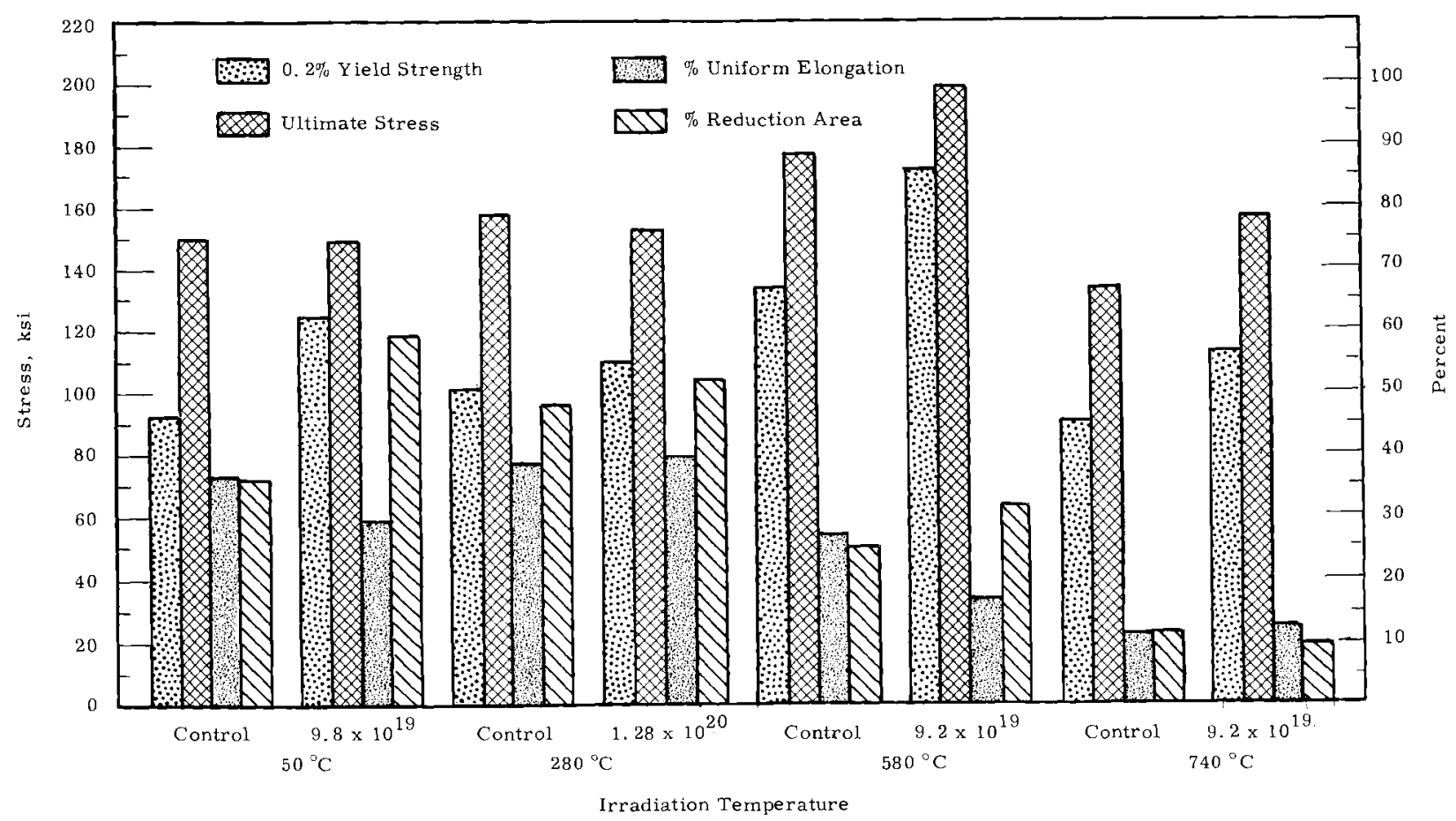

\section{FIGURE 7}

Effects of Irradiation Temperature Upon the Room Temperature Properties of Inconel 625 Irradiated to an Exposure of About $1 \times 10^{20}$ nvt (E>1 MeV)

Specimens irradiated at $580{ }^{\circ} \mathrm{C}$ and tested at room temperature show a greater percentage increase in yield strength than those irradiated at $740{ }^{\circ} \mathrm{C}$. The lower temperature irradiation increased the yield strength by $27 \%$, compared to a $12 \%$ increase for the $740{ }^{\circ} \mathrm{C}$ irradiation. However, a marked decrease in uniform elongation (from $27 \%$ to about $18 \%$ ) resulted from an exposure of $9.2 \times 10^{19} \mathrm{nvt}(\mathrm{E}>1 \mathrm{MeV})$ at $580{ }^{\circ} \mathrm{C}$. An irradiation temperature of $740^{\circ} \mathrm{C}$ caused little if any change to either reduction of area or uniform elongation. It is evident that by comparing the control data to the irradiation data, most of the decrease in uniform elongation is due not to the irradiation but to the thermal exposure of the material in its environment.

As previously mentioned, specimens of Inconel 625 in the millannealed condition were irradiated for comparison with those in the solutiontreated and aged condition. The results of these tests, performed at room 
temperature for specimens irradiated at $740^{\circ} \mathrm{C}$, are shown in Figure 8 . For the solution-treated and aged specimen, only srnall differences in uniform and total elongation, and reduction of area were found between the control and irradiated specimens. A $22 \%$ increase in yield strength was found due to the irradiation. Similar statements are true for the annealed specimens.

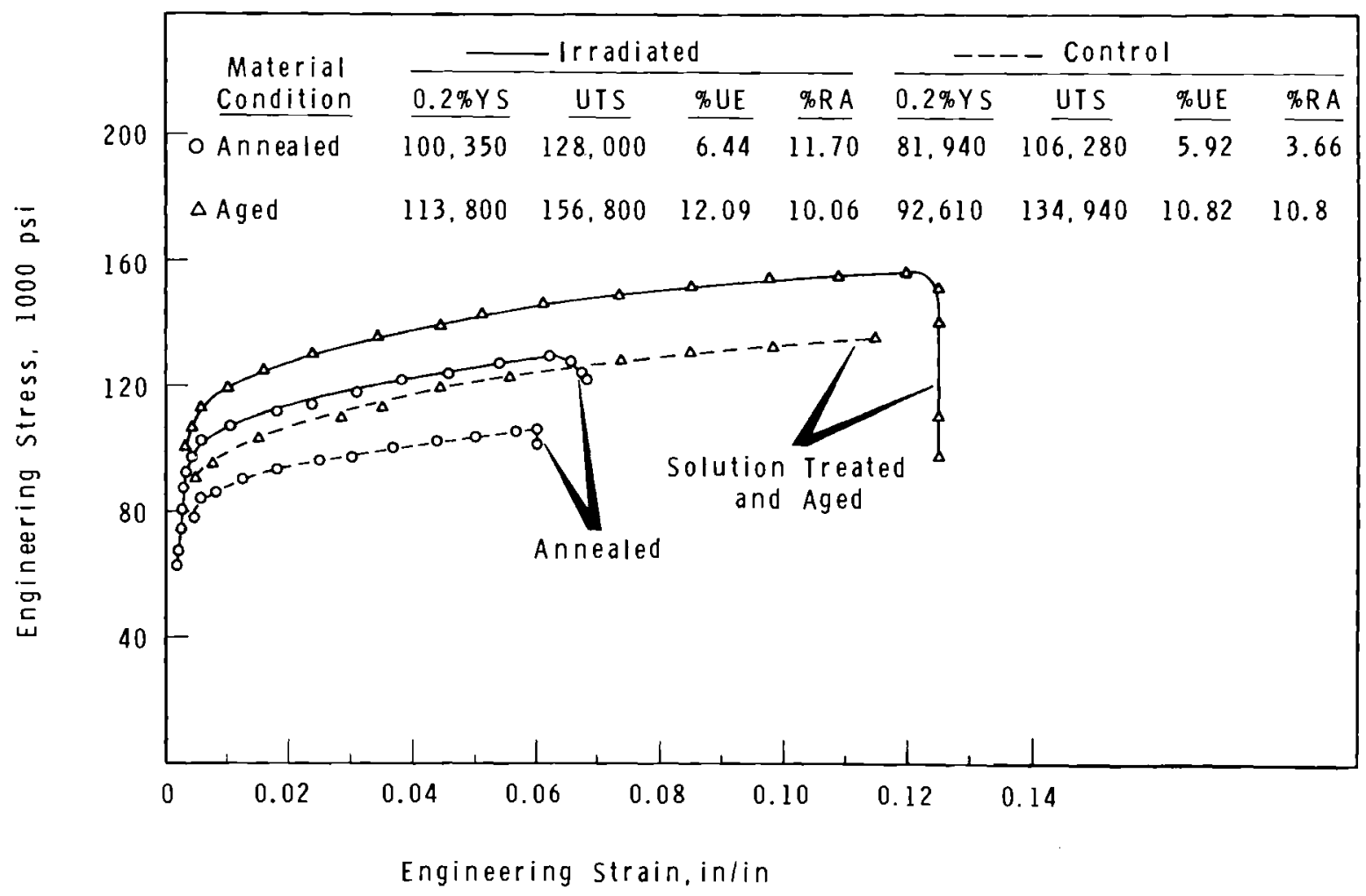

FIGURE 8

Effects of Irradiation Upon the Room Temperature Properties of Inconel 625 in the Annealed and Solution Treated-Aged Condition

Irradiated at $740^{\circ} \mathrm{C}$ to an Exposure of $9 \times 10^{19} \mathrm{nvt}(\mathrm{E}>1 \mathrm{MeV})$

Neg. $0643021-6$

Comparison of the annealed to the solution-treated and aged specimens shows that solution-treated and aged specimens maintained higher strengths and more ductility before and after irradiation. Specimens in both conditions increased in yield strength about $22 \%$ and indicated little relative difference in radiation hardening. 
B. Effects of Irradiation Upon the Elevated Temperature Mechanical Properties of Inconel 625

Specimens of Inconel 625 were irradiated at $740^{\circ} \mathrm{C}$ to a maximum exposure of $1.9 \times 10^{20} \mathrm{nvt}(\mathrm{E}>1 \mathrm{MeV})$ and tested at $300^{\circ} \mathrm{C}$ (Figure 9).

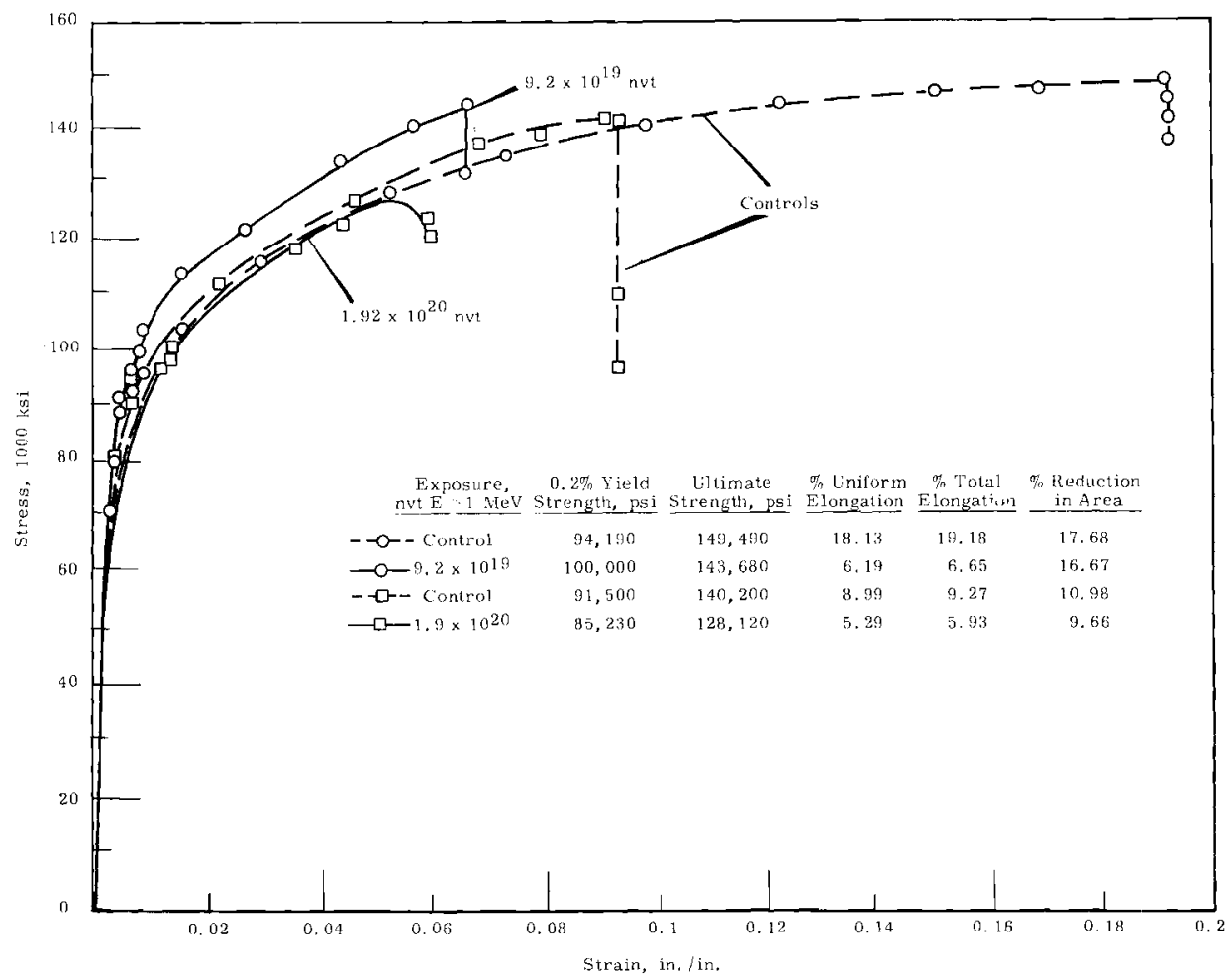

FIGURE 9

Effect of Neutron Irradiation Upon the Mechanical Properties of Inconel 625 Irradiated at $740^{\circ} \mathrm{C}$ and Tested at $300^{\circ} \mathrm{C}$

The yield strength of the specimens irradiated to $9.2 \times 10^{19}$ nvt was 100,000 psi as compared to 94,190 psi for the control (an increase of about $7 \%$ ). Some increase $(\approx 4 \%$ ) was also found in the ultimate strength. A considerable decrease in ductility was found as shown in Figure 9. The uniform elongation decreased from $18.1 \%$ for the unirradiated control specimen to $6.19 \%$ for the irradiated material. Similar decreases can be seen in the total elongation. The reduction of area of the specimens remained unchanged at approximately $17 \%$.

For the specimens irradiated to $1.9 \times 10^{20}$ nvt at $740{ }^{\circ} \mathrm{C}$, the $300{ }^{\circ} \mathrm{C}$ tensile properties show further reduction in strength and ductility as compared 
to specimens irradiated to lower exposure. Most of this decrease is because of the thermal exposure over a longer period of time as shown by the comparison to the control specimen corresponding to the higher exposure. The yield strength of the longer exposure specimens was decreased by the irradiation as compared to the control specimens while the yield strength of the lower exposure specimens was increased slightly (Figure 9).

The effects of irradiation at $280{ }^{\circ} \mathrm{C}$ upon the mechanical properties of Inconel 625 at $650{ }^{\circ} \mathrm{C}$ have been determined as shown in Figure 10. Results of these tests indicate little change in yield strength of the material at exposures to $1.46 \times 10^{21}$ nvt $(\mathrm{E}>1 \mathrm{MeV})$. The greatest change occurred in the ultimate strength which decreased about $25 \%$. In addition, low ductilities, including the control specimens, were noted throughout the tests. Values of uniform elongation as low as $4.5 \%$ at $1.46 \times 10^{21}$ nvt were found which indicated the material retained about the same ductility as the unirradiated specimen.

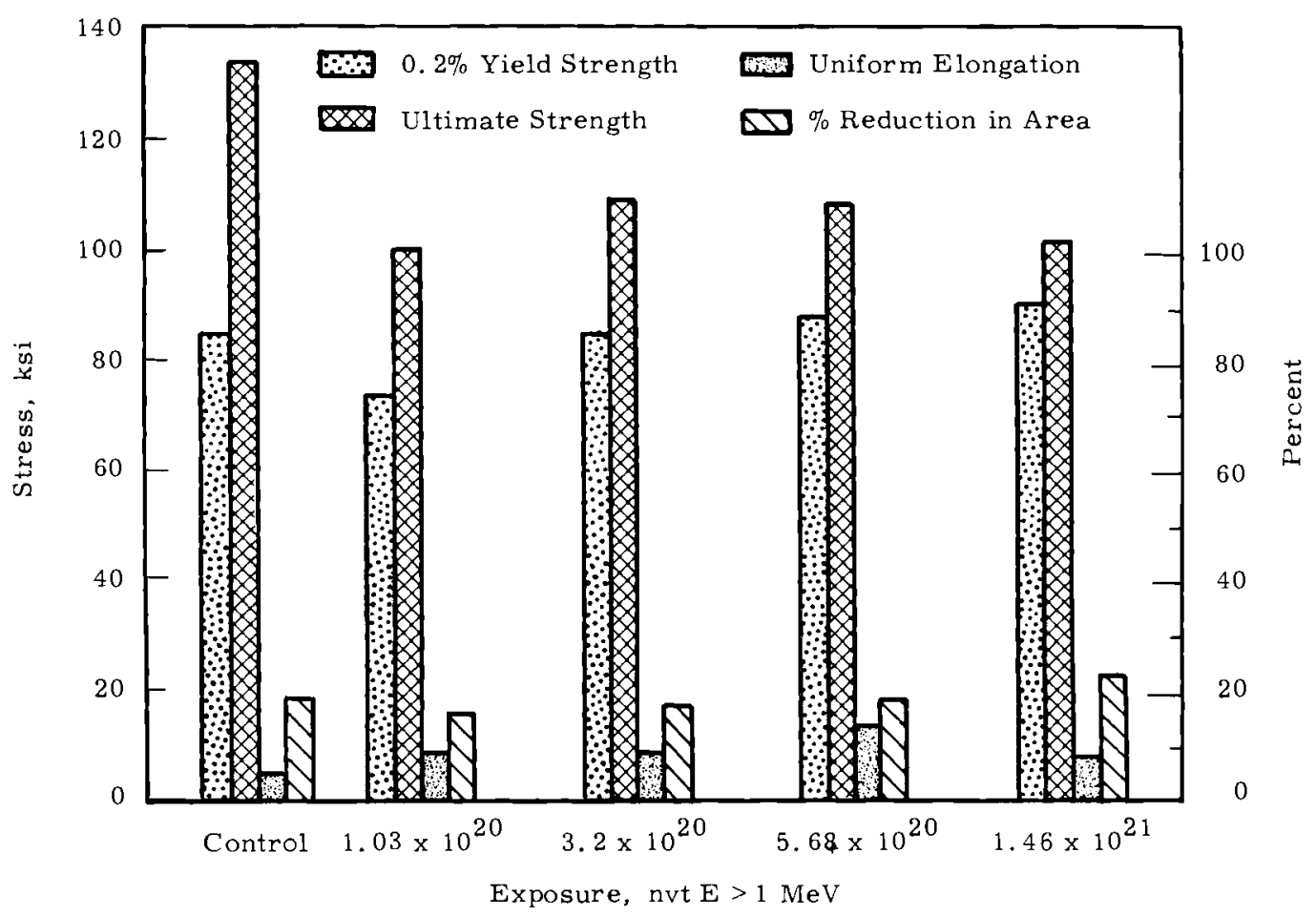

FIGURE 10

Effects of Irradiation at $280^{\circ} \mathrm{C}$ Upon the Mechanical Properties of Inconel 625 Tested at $650{ }^{\circ} \mathrm{C}$ in the Solution Treated Condition 
Specimens irradiated at $740^{\circ} \mathrm{C}$ to an exposure of $9 \times 10^{19} \mathrm{nvt}$ in the mill annealed and solution treated conditions were also tested at $650^{\circ} \mathrm{C}$. The results of these tests are shown in Figure 11 . The effect of the solution treatment in the unirradiated control specimens was to increase somewhat the strength and ductility of the material. After irradiation at $740^{\circ} \mathrm{C}$, the strength and ductility of the material in both the solution heat treated and annealed condition were substantially reduced. Whereas, before irradiation, the solution treated material showed the higher strength, this material exhibited a greater loss in strength after irradiation. However, it is important to note that the solution treated material maintained more ductility after irradiation than did the material in the mill annealed condition even though it had lower strength properties.

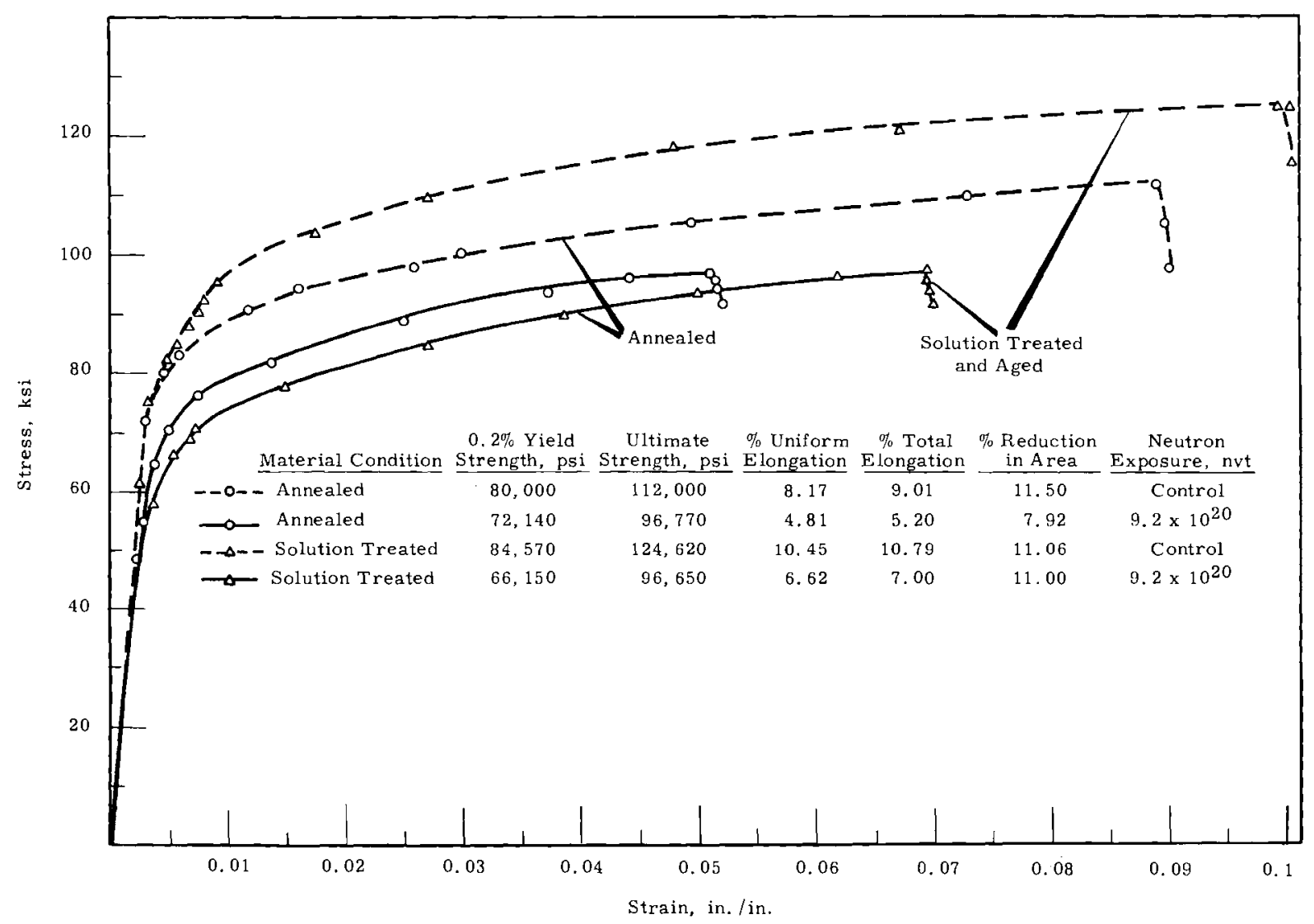

FIGURE 11

Effects of Neutron Irradiation Upon the $650{ }^{\circ} \mathrm{C}$ Mechanical Properties of Inconel 625 Irradiated at $740{ }^{\circ} \mathrm{C}$ in the Mill Annealed and Solution Treated Conditions to an Exposure of $9 \times 1019 \mathrm{nvt}(\mathrm{E}>1 \mathrm{MeV})$ 
Table III lists $650^{\circ} \mathrm{C}$ tensile data for irradiated and control specimens of Inconel 625. Comparison of the data for Specimen 59 with Specimen A 45X shows that the thermal aging at $740^{\circ} \mathrm{C}$ given Specimen A45X does not affect the high temperature strength properties of the material.

As previously explained, the control specimens were given a thermal exposure equivalent to the irradiated specimens. The comparison of data indicates a small (1010 psi) increase in yield strength and a decrease (5000 psi) in ultimate strength. A decrease in ductility was also found as show $n$ by the uniform and total elongation $(\Delta \mathrm{e} \simeq 9 \%)$ and reduction of area $(\triangle \mathrm{RA} \simeq 6 \%)$ values. Specimen $\mathrm{A} 39 \mathrm{X}$ in the mill annealed condition shows a reduction in strength and ductility when compared to Specimen 59 . The actual differences in the properties found are then primarily due to both thermal environment and irradiation.

TABLE III

TENSILE DATA FOR IRRADIATED AND CONTROL SPECINENS OF INCONEL 625

\begin{tabular}{|c|c|c|c|c|c|c|c|c|c|}
\hline $\begin{array}{c}\text { Specimen } \\
\text { No. }\end{array}$ & $\frac{\text { Temperatur }}{\text { Irradiation }}$ & $=\frac{{ }^{C} \mathrm{C}}{\text { Test }}$ & $\begin{array}{l}0.2 \% \text { Yield } \\
\text { Strength psi }\end{array}$ & $\begin{array}{c}\text { Ultimate } \\
\text { Strenoth }\end{array}$ & \% Uniform & $\begin{array}{c}\% \text { Total } \\
\text { Elongation }\end{array}$ & $\begin{array}{l}\% \text { Reduction } \\
\text { in Area }\end{array}$ & $\begin{array}{l}\text { Material } \\
\text { Condition }\end{array}$ & $\begin{array}{l}\text { Neutron } \\
\text { Exposure, nvt }\end{array}$ \\
\hline 59 & -- & 650 & 83,580 & 129,600 & 19.05 & 19.96 & 16.92 & $\begin{array}{l}\text { Solution } \\
\text { Treated }\end{array}$ & 0 \\
\hline $373-D 3$ & 50 & 650 & 107,940 & 125,660 & 7.16 & 8.00 & 17.46 & $\begin{array}{l}\text { Solution } \\
\text { Treated }\end{array}$ & $1.71 \times 10^{21}$ \\
\hline A $39 X$ & -- & 650 & 80,000 & 112,000 & 8.17 & 9.01 & 11.50 & Annealed & 0 \\
\hline A 40 & 740 & 650 & 72,140 & 96,770 & 4.81 & $5: 20$ & 7.96 & Annealed & $9.2 \times 10^{19}$ \\
\hline A $45 X$ & -- & 650 & 84,570 & 124,600 & 10.45 & 10.79 & 11.06 & $\begin{array}{l}\text { Solution } \\
\text { Treated }\end{array}$ & 0 \\
\hline A 46 & 740 & 650 & 66,150 & 96,650 & 6.62 & 7.00 & 11.00 & $\begin{array}{l}\text { Solution } \\
\text { Treated }\end{array}$ & $9.2 \times 10^{19}$ \\
\hline
\end{tabular}




\section{ONSITE DISTRIBUTION}

Copy Number

Pacific Northwest Laboratory

1
2
3
4
5
6
$7-26$
27
28
29
30
31
32
33
34
35
36
37
38
39
40
41
42
43
44
45
46
47
$48-52$
53
$54-55$

F. W. Albaugh

J. A. Ayres

A. L. Bement

W. A. Burns

S. H. Bush

J. J. Cadwell

T. T. Claudson

G. M. Dalen

R. F. Dickerson

R. L. Dillon

S. L. Fawcett

J. L. Humason

J. E. Irvin

J. H. Johnson

R. S. Kemper

G. A. Last

J. E. Minor

D. N. Nyman

D. P. O'Keefe

R. E. Olson

F. E. Say

R. Teats

F. W. Van Wormer

K. R. Wheeler

R. G. Wheeler

O. J. Wick

R. D. Widrig

J. A. Williams

Technical Information Files

Technical Publications, 300

Technical Publications, 700

General Electric Company, Richland

56
57
58
59
60

D. H. Curtiss

M. C. Leverett

M. Lewis

J. W. Riches

GETA File Copy

\section{Richland Operations Office}

P. G. Holsted

L. R. Lucas

R. K. Sharp

63

Technical Information Library 


\section{OFFSITE DISTRIBUTION (Special)}

No. of Copies
Aktiebolaget Atomenergi

P. O. Box 9042

Stockholm 9, Sweden

Attn: Gustaf Ostberg

Aeronautical Systems Division

Air Force Systems Command

Headquarters, Directorate of Materials and Processes Attn: Col. L. J. Standifer

Allis-Chalmers Manufacturing Company

Atomic Energy Division

Nuclear Power Department, Washington

P. O. Box 5976

Washington, D. C. 20014

Attn: J. F. Haines

Argonne National Laboratory

Attn: R. J. Armani

T. H. Blewitt

J. H. Kittel

F. D. McGinnis - EBR-I, Idaho Falls, Idaho

A. D. Rossin

D. K. Youngdahl

Atomic Energy Research Establishment Harwe11, England

Attn: Dr. R. S. Barnes

Dr. D. R. Harries

Atomic Energy Commission, Washington Advisory Committee on Reactor Safeguards Attn: R. F. Fraley, Executive Secretary

Atomic Energy Commission, Washington Division of Licensing and Regulation

Attn: M. Bolotsky

E. G. Case

J. J. DiNunno

A. B. Holt

Atomic Energy Commission, Washington Division of Reactor Development

Attn: I. H. Mandil

J. L. Mershon

W. L. R. Rice

J. M. Simmons

R. H. Steele

S. A. Szawlewics

N. J. Triner 


\section{OFFSITE DISTRIBUTION (Special)(contd)}

No. of Copies
Atomic Energy Commission, Washington

Division of Research

Attn: D. K. Stevens

AEC Scientific Representative

USAEC London Office

U. S. Embassy

London, England

Attn: S. G. Nordlinger

Battelle Memorial Institute

Attn: F. R. Shober

Brookhaven National Laboratory

Attn: J. G. Y. Chow

D. H. Gurinsky

Chicago Operations Office

Attn: Claude Pursel.

Combustion Engineering Corporation

Attn: John Gibbons

Division of Technical Information Extension

Attn: J. W. Norris, Chief, Cataloging Branch

Engineer Research and Development Center

Fort Belvoir, Virginia 20060

Attn: George Knighten, Nuclear Power Field Office

General Atomic Division

Attn: T. A. Trozera

W. P. Wallace

General Electric Company, Cincinnati

Attn: C. L. Brassfield

F. E. Kingsbury

J. McGurty

J. Moteff

R. C. Rau

F. C. Robertshaw

J. R. Smith

General Electric Company, Pleasanton

Attn: L. P. Bupp

E. A. Evans

General Electric Company, San Jose

Attn: F. A. Comprelli

C. N. Spalaris

Idaho Operations Office

Attn: J. K. Kaufmann 
OFFSITE DISTRIBUTION (Special)(contd)

\section{No. of Copies}

1

1

2

2
Knolls Atomic Power Laboratory

Attn: J. Van Ullen

Materials Advisory Board

National Academy of Sciences

2101 Consitution Avenue, N. W.

Washington 25, D. C.

Attn: J. R. Lane

NASA Lewis Research Center

Attn: M. L. Ault

M. Krasner, Nuclear Reactor Division

National Reactor Testing Station (PPCO)

Attn: J. M. Beeston

W. C. Francis

National Reactor Testing Station (PPCO)

Nuclear Materials and Propulsion Operation

P. O. Box 2147

Idaho Falls, Idaho

Attn: A. T. Lovell

Naval Research Laboratory

Attn: J. W. Haw thorne

L. E. Steele

Oak Ridge National Laboratory

Attn: R. G. Berggren

W. E. Brundage

N. E. Hinkle

E. C. Miller

S. M. Ohr

J. T. Stanley

M. S. Wechsler

J. R. Weir

J. M. Williams

F. W. Young

Oak Ridge Operations Office

Attn: D. F. Cope

H. J. Pess1

Route 1, Box 892

Hood River, Oregon

San Francisco Operations Office

Attn: C. Washburn, Reactor Division 


\section{OFFSITE DISTRIBUTION (Special)(contd)}

\section{No. of Copies}

1

1

1

1
Special Assistant for Materials

DDR\&E

The Pentagon

Washington 25, D. C.

Attn: E. T. Hayes

U. S. Mission to the European Communities

23 Avenue des Artes

Brussels, Belgium

Attn: J. A. Erlewine, Senior AEC Representative, Brussels Office

University of Cincinnati

Dept. of Chemical Engineering and Metallurgical

Engineering

Cincinnati 21, Ohio

Attn: A. E. Focke

Westinghouse Bettis Atomic Power Laboratory

Attn: R. H. Fillnow

Westinghouse Electric Corporation

Attn: E. Landerman 
5

k

$\cdot$ 